\title{
Evaluation of Genetic Damage to Workers in a Nickel Smelting Industry
}

\author{
Efthymios Thanasias', Dimitris Koutsoumplias², Dimitris Vlastos², George Halkos ${ }^{3}$, \\ Demetrios Matthopoulos ${ }^{2}$ (1) Vassilis Makropoulos $^{1}$
}

\footnotetext{
${ }^{1}$ Department of Occupational and Industrial Hygiene, National School of Public Health, Athens, Greece

${ }^{2}$ Department of Environmental and Natural Resources Management, University of Patras, Patras, Greece

${ }^{3}$ Department of Economics, University of Thessaly, Volos, Greece

Email: dmatthop@upatras.gr
}

How to cite this paper: Thanasias, E., Koutsoumplias, D., Vlastos, D., Halkos, G., Matthopoulos, D. and Makropoulos, V. (2019) Evaluation of Genetic Damage to Workers in a Nickel Smelting Industry. Occupational Diseases and Environmental Medicine, 7, 21-35.

https://doi.org/10.4236/odem.2019.71003

Received: January 29, 2019

Accepted: February 19, 2019

Published: February 22, 2019

Copyright $\odot 2019$ by author(s) and Scientific Research Publishing Inc. This work is licensed under the Creative Commons Attribution-NonCommercial International License (CC BY-NC 4.0). http://creativecommons.org/licenses/by-nc/4.0/ (c) (i) \& Open Access

\begin{abstract}
Objectives: Occupational exposure to nickel is affecting millions of employees around the world. Potential alterations in the genetic material of workers in the mining and processing of nickel, possibly resulting from exposure to nickel in the production process, were investigated. The study focused on assessing the percentage of induced micronuclei, as well as on changes in the various cell types of oral mucosa epithelium. Methods: The buccal micronucleus assay was employed to assess possible induced genetic alterations to production line workers in comparison to office employees of the same nickel mining and pyrometalurgic processing industry. Subjects were also compared with regard to their smoking habit. Results: Very low soluble nickel levels were measured in certain workplaces and only in one workplace insoluble nickel was above the acceptable level. Statistically significant micronuclei differences among smokers and non-smokers, in both study groups as well as in total, were observed ( $p$ less than 0.01 ). Production line workers appeared with statistically significant induced micronuclei compared to office employees. Non-smoker production line workers compared to non-smoker office employees revealed statistically significant induced micronuclei. Statistically significant cell lesions were detected between non-smokers and smokers among office employees and production line workers documenting Ni engagement in their induction. Conclusions: The observed frequencies of micronuclei and cell lesions in the oral mucosa of workers, in certain positions of the production line, in relation to their smoking habit document the synergistic effect of $\mathrm{Ni}$ and cigarette smoking as effectors in their induction.
\end{abstract}

\section{Keywords}

Metallic Nickel, Soluble Nickel, Micronuclei, Occupational Exposure, Buccal 
Micronucleus Cytome Assay, Smoking Habit

\section{Introduction}

Nickel (Ni) is the fifth most common element on Earth and is mainly found as sulfur, oxides and salts minerals. It is an important commercial product due to its special characteristics and is mainly used in the production of stainless steel as ferronickel (FeNi).

Occupational exposure to $\mathrm{Ni}$ affects millions of workers worldwide working in industrial mining, refining and production of $\mathrm{Ni}$ alloys, welding procedures and chemical catalysts with $\mathrm{Ni}$ compounds. The primary way of exposure to $\mathrm{Ni}$ is through inhalation of aerosols, dust and smoke containing $\mathrm{Ni}$ [1]. $\mathrm{Ni}$ is found in cigarettes and its content is estimated at $2.32-4.20 \mathrm{mg} / \mathrm{kg}$ and $2.20-4.91 \mathrm{mg} / \mathrm{kg}$ in smoke [2]. The absorption of inhaled Ni particles depends on the particle size and their solubility. The soluble Ni sulfate is absorbed faster than other Ni minerals [3] [4].

Exposure to sulfides, $\mathrm{NiS}$ and $\mathrm{Ni}_{3} \mathrm{~S}_{2}$, was associated with lung cancer in several epidemiological studies in Ni mills in Canada [5] and Norway [6]. Studies indicate that metallic Ni is less likely to be carcinogenic to humans [7] [8]. According to Grimsrud et al. [9], there is a dose dependent relationship between lung cancer and the water-soluble $\mathrm{Ni}$ compounds. Soluble forms of Ni enhance the risk associated with exposure to insoluble forms of $\mathrm{Ni}$ [10]. The International Agency for Research on Cancer (IARC) indicated that there is sufficient evidence for the carcinogenicity of $\mathrm{Ni}$ sulfate and combinations of $\mathrm{Ni}$ sulfides and oxides in professional environments and thus classified soluble forms of $\mathrm{Ni}$ in group 1. Furthermore, IARC concluded that there is insufficient evidence that metallic $\mathrm{Ni}$ is carcinogenic to humans, and classified metallic $\mathrm{Ni}$ and $\mathrm{Ni}$ carbonyl as potentially carcinogenic to man in category $2 \mathrm{~B}$, based on sufficient evidence of being carcinogenic to animals [11].

The primary targets, for carcinogenesis induced by $\mathrm{Ni}$, are the nasal cavity and the lungs. The cells of the oral epithelium, forming the first barrier to respiratory and digestive tract, are capable of metabolizing carcinogens into active products [12]. Thus, alterations observed in buccal and nasal epithelium cells may provide indications of possible side effects from the exposure to various harmful agents.

Many bio-monitoring studies, in order to investigate the possibility of side effects from the exposure to various harmful agents, used the micronucleus assay in human buccal mucosa cells (Buccal Micronucleus Cytome assay, BMCyt assay) [13]-[26].

Micronuclei are small masses of chromatin or chromosome fragments (DNA fragments) that during mitosis do not arrive at the poles of the spindle in telophase and remain encapsulated as a separate core outside the main cell nucleus [27] [28] leading to potential aneuploidies. Because aneuploidies are key factors 
in the development of malignancies [29], micronuclei act as internal dosimeters for the disclosure of specific genotoxic tissue damage in workers exposed to carcinogens [30] [31].

The present study aims to investigate the potential genetic damage of workers occupationally exposed in a large Greek industry of mining, manufacturing and processing $\mathrm{Ni}$. The company uses pyro-metallurgy to extract $\mathrm{Ni}$ and the annual production is $18,000-20,000$ tons of $\mathrm{Ni}$. For this purpose the buccal micronucleus assay was used in order to determine the extent of genetic damage, in terms of micronuclei formation, from exposure to $\mathrm{Ni}$. In addition, potential differences in the degree of oral mucosa cell lesions were estimated in workers exposed to soluble and insoluble Ni. Moreover, since according to several studies smoking causes cellular lesions to oral mucosa [32] [33] [34] [35] and also cigarette smoke contains $\mathrm{Ni}$ [2], a further objective of the study was to compare the induced alterations in the genetic material of smoking workers in relation to non-smokers.

\section{Materials and Methods}

\subsection{Study Group}

The study was carried out on a group of 59 workers of a large industry of mining, manufacturing and processing $\mathrm{Ni}$, occupationally exposed to different concentrations of $\mathrm{Ni}$ (soluble and in-soluble). The participants in the present study were divided into two groups: a) control group: 13 office employees (nine males and four females) with no contact with the dust of the production process (white collar workers, WCW) and b) exposed group: 46 employees in the production procedure of $\mathrm{Ni}$ (blue collar workers, BCW, they all were males). Each of these groups was then subdivided into smokers and non-smokers (Table 1).

In the present study one shift office employees and exposed workers were included. Newcomer workers were excluded from the study. Furthermore, a number of employees and workers were excluded from the study as they were under medication, at least for a three months period prior to the sampling day, according to the instructions of their occupational physician. A full and updated medical record was kept for all participants in the study. In their records there was no report of heavy alcohol consumption or cancer incident in their family.

All participants in the present study signed a consent document declaring that are aware of the study and its purposes. The study was approved by the Ethical Committees of the National School of Public Health and the University of Patras, Greece

\subsection{Nickel Measurements}

The concentration of $\mathrm{Ni}$, in the breathable and inhalable fraction of suspended particles in the air of 10 workplaces in the production process of the company, was measured using a portable personal sampler, (3-stages personal impactor RESPICONTM-Helmut Hund $\mathrm{GmbH}$ ). The determination of $\mathrm{Ni}$ and its inorganic 
Table 1. Distribution of the participants in the study groups.

\begin{tabular}{|c|c|c|c|c|}
\hline \multirow{2}{*}{ Subjects } & \multicolumn{4}{|c|}{ Number of Employees } \\
\hline & \multicolumn{4}{|c|}{ Gender } \\
\hline Control (office employees, WCW) & Males & \multicolumn{2}{|r|}{ Females } & Total \\
\hline Smokers & 1 & \multicolumn{2}{|r|}{2} & 3 \\
\hline Non-smokers & 8 & \multicolumn{2}{|r|}{2} & 10 \\
\hline \multirow[t]{2}{*}{ Total (controls) } & 9 & \multicolumn{2}{|r|}{4} & 13 \\
\hline & \multicolumn{4}{|c|}{ Years of Exposure } \\
\hline Exposed Workers $(\mathrm{BCW})^{\mathrm{a}}$ & $2-10$ & $11-20$ & 20 - over & Total \\
\hline Smokers & 23 & 5 & 4 & 32 \\
\hline Non-smokers & 6 & 3 & 5 & 14 \\
\hline Total (exposed workers) & 29 & 8 & 9 & 46 \\
\hline
\end{tabular}

WCW: white collar workers, BCW: blue collar workers, a: all BCWs were males.

compounds in the respirable fraction of suspended particles (RSP) was conducted according to the Standard-MDHS Procedure 42/2 [36] [37] [38] [39] and was expressed in $\mathrm{mg} / \mathrm{m}^{3}$ (Table 2). The Ni Institute (NI) reports different $\mathrm{Ni}$ limit values for various countries, however, a limit value of $0.01 \mathrm{mg} / \mathrm{m}^{3}$ is widely acceptable [40].

According to the participants in the present study the plant was divided into: 1) Offices, where Ni processing by-products are not present in the air, 2) Sander, in the proximity of the mining place but far away of the pyro-metallurgic processing plant, and 3) the main Ni processing plant comprised by the Demineralization, Cranes, Dome, Electrical Furnaces, Granulation, Steelworks, and Forge workplace areas.

\subsection{Epithelial Cells Sampling}

Buccal cell samples were collected, after the end of work-shifts. Subjects prior to sampling washed thoroughly their mouth with tap water. Exfoliated epithelial cells of buccal mucosa were obtained by means of a manual toothbrush which was rotated ten times, with light pressure, on the middle part of the inner cheek, paying attention not to strike on teeth. The epithelial cells collected from buccal mucosa were transferred in sterile tubes containing phosphate buffered saline (PBS) and properly transported under refrigeration to the laboratory for further processing.

The buccal micronucleus Cytome assay (BMCyt assay) was used to measure biomarkers of DNA damage (micronucleated cell, micronuclei and/or elimination of nuclear material by budding-buds), cytokinetic defects (binucleated cells), proliferative potential (basal and differentiated cell frequency) and/or cell death (condensed chromatin, Karyorrhectic, Pyknotic and Karyolytic cells). BMCyt assay was performed according to standard procedures [20] [41] with minor modifications. 
Table 2. Nickel (soluble and/or insoluble) concentration $\left(\mathrm{mg} / \mathrm{m}^{3}\right)$ in the various workplaces of the plant.

\begin{tabular}{ccc}
\hline Workplace & Insoluble Ni & Soluble Ni \\
\hline Offices & Not detected & Not detected \\
Sander & Not measured & Not measured \\
Demineralization & 0.0203 & 0.0012 \\
Cranes & Not detected & Not detected \\
Dome & 0.0066 & 0.001 \\
Dome Caretaker & Not detected & Not detected \\
Electrical Furnaces & 0.0048 & 0.0002 \\
Granulation & Not detected & Not detected \\
Steel Works & Not detected & 0.0012 \\
Forge Caretaker & 0.0059 & Not detected \\
\hline
\end{tabular}

The phosphate buffered saline with the epithelial cells collected from buccal mucosa was centrifuged at $2000 \mathrm{rpm}$ for $5 \mathrm{~min}$ to sediment buccal cells that next were twice washed with saline and once more with Carnoy's fixative (methanol and glacial acetic acid 3:1) under the same centrifugation conditions.

Cell suspensions were dropped onto thoroughly alcohol-cleaned slides and allowed to air dry at room temperature. The slides were stained with 7\% Giemsa solution for $5 \mathrm{~min}$, rinsed in distilled water, and air dried. For each individual, the frequency of the various buccal cell types per 1000 cells and the number of micronuclei in a total of 2000 cells were scored. Duplicate microscope slides were prepared and analyzed per subject.

The study focused on observing changes in the various cell types of the oral mucosa epithelium, as well as on assessing the percentage of induced micronuclei, as biomarkers. Thus, oral epithelium samples were processed according to the buccal micronucleus assay protocol [20] [41]. Annotated microscope slide preparations were observed with a Leica DMLB (400× magnification) microscope by a researcher who was not aware of any parameter of the samples.

\subsection{Statistical Analysis}

To overcome the small number of subjects participated in the present study and their distribution in the various workplaces non-parametric analysis (MannWhitney and Kruskal-Wallis tests with the use of SPSS17 [SPSS Inc.]) was employed in order to compare the calculated data from the BMCyt assay. The various employee groups were compared according to their smoking habits and their exposure to $\mathrm{Ni}$ compounds, soluble or insoluble. In addition to non-parametric statistical analysis, $\chi^{2}$ and G-test for independence on $2 \times 2$ tables were used for additional data comparison with the use of Minitab statistical software (Minitab Inc., Pennsylvania, USA). 


\section{Results}

\subsection{Smoking Habit-Exposure}

The subjects that participated in the present study were $42.7 \%$ non-smokers and $57.3 \%$ smokers (Table 1). The $68 \%$ of blue collar workers were smokers. The average exposure of $\mathrm{BCW}$ to $\mathrm{Ni}$ according to their working years, in positions where $\mathrm{Ni}$ at any form was detected, it was 10.83 years. 17 out of the $46 \mathrm{BCWs}$ were exposed to metallic $\mathrm{Ni}$ in their working place, 15 were exposed to soluble $\mathrm{Ni}$, while 14 were simultaneously exposed to soluble and insoluble $\mathrm{Ni}$.

The difficulties encountered in the study focused on: 1) the heterogeneity of the sample in relation to smoking habits, as most of the production workers are smokers and 2) the exposure time of the individuals to Ni based on measurements made per workplace. Because of the extremely difficult working conditions at certain places of the production process (increased number of accidents, high temperatures, musculoskeletal strain, etc) a shift of workers between workplaces takes regularly place. This shifting renders all BCWs to be homogeneously exposed to either soluble or insoluble Ni during their working years.

\subsection{Nickel (Ni) Measurements}

With the use of a personal cascade impactor sampler and following the Standard-MDHS Procedure 42/2 for the determination of $\mathrm{Ni}$ and its inorganic compounds, insoluble and soluble $\mathrm{Ni}$ was measured in the various working places of company's production process. Table 2 depicts the results of these measurements. The main observation is that, in all places that measurements were performed, insoluble $\mathrm{Ni}$ concentration was below the international limit of $0.01 \mathrm{mg} / \mathrm{m}^{3}$, except for the Demineralization area, while soluble $\mathrm{Ni}$ was not measured above the international limit at any working place [40]. In the Sander area, located near the mines, there was no $\mathrm{Ni}$ measurement performed as it is located in a large distance from the main plant where soluble and insoluble $\mathrm{Ni}$ may be suspended in the air.

\subsection{Buccal Micronucleus Cytome (BMCyt) Assay Measurements and Analysis}

Oral mucosa cell samples, from all participants in the study, were prepared and observed microscopically by an independent researcher. Cells were classified into various types (Basal, Differentiated, Binucleated, Micronucleated, Condensed, Karyorrhectic, Pycnotic, Karyolytic) according to Thomas et al. [20]. All subjects were divided into smokers and non-smokers. 1000 cells were observed per slide and scored to identify the various cell types.

Non-parametric analysis between smokers at the various work-places (Table 3) revealed statistically significant differences (Table 4) between office employees (WCWs) and exposed workers (BCWs) in cells with micronuclei. Statistically significant differences were also detected between non-smokers and smokers regardless their work-places. In the WCWs, between non-smokers and 
Table 3. The frequencies (\%o) of the various cell types in exfoliated epithelial cells of control and exposed subjects ${ }^{\mathrm{a}}$.

\begin{tabular}{ccccc}
\hline \multirow{2}{*}{ Cell types } & \multicolumn{4}{c}{ Subjects } \\
\cline { 2 - 5 } & WCW ns & WCW s & BCW ns & BCW s \\
\hline Basal & $0.60 \pm 0.16$ & $0.50 \pm 0.19$ & $0.86 \pm 0.10$ & $0.89 \pm 0.06$ \\
Differentiated & $418.00 \pm 36.26$ & $439.38 \pm 26.20$ & $375.29 \pm 33.70$ & $310.89 \pm 19.89$ \\
Binucleated & $2.40 \pm 0.34$ & $3.24 \pm 0.49$ & $2.57 \pm 0.31$ & $2.96 \pm 0.22$ \\
Micronucleated & $4.30 \pm 0.30$ & $6.50 \pm 0.46$ & $6.21 \pm 0.33$ & $8.63 \pm 0.49$ \\
Condensed & $1.60 \pm 0.37$ & $1.63 \pm 0.26$ & $2.50 \pm 0.36$ & $2.63 \pm 0.22$ \\
Karyorrhectic & $39.90 \pm 4.90$ & $66.88 \pm 6.54$ & $53.07 \pm 3.57$ & $57.15 \pm 3.02$ \\
Pycnotic & $101.90 \pm 10.13$ & $131.00 \pm 5.79$ & $110.79 \pm 6.89$ & $119.41 \pm 5.89$ \\
Karyolytic & $431.30 \pm 44.19$ & $350.88 \pm 25.83$ & $449.50 \pm 35.86$ & $498.56 \pm 21.65$ \\
\hline
\end{tabular}

a: Mean \pm standard error, WCW: white collar workers, BCW: blue collar workers, ns: non-smokers, s: smokers.

Table 4. Non parametric analysis of WCWs versus BCWs as well as non-smokers versus smokers.

\begin{tabular}{|c|c|c|c|c|c|c|c|c|}
\hline \multirow{4}{*}{ Cell Types } & & \multicolumn{7}{|c|}{ Subjects } \\
\hline & & \multirow{2}{*}{\multicolumn{2}{|c|}{$\begin{array}{c}\text { WCWs } \\
\text { NS/S }\end{array}$}} & \multirow{2}{*}{\multicolumn{2}{|c|}{$\begin{array}{l}\text { BCWs } \\
\text { NS/S }\end{array}$}} & \multicolumn{3}{|c|}{ WCWs versus BCWs } \\
\hline & & & & & & \multirow{2}{*}{$\begin{array}{c}\text { WCWs } \\
\text { Mean } \pm \text { s.e. }\end{array}$} & \multicolumn{2}{|l|}{ BCWs } \\
\hline & & Mean \pm s.e. $^{a}$ & ${ }^{*} \mathrm{p}$ & Mean \pm s.e. $^{a}$ & ${ }^{*} \mathrm{p}$ & & Mean \pm s.e. $^{\mathrm{a}}$ & ${ }^{*} \mathrm{p}$ \\
\hline \multirow{2}{*}{ Basal } & NS & $0.60 \pm 0.16$ & \multirow{2}{*}{$>0.05$} & $0.86 \pm 0.10$ & \multirow{2}{*}{$>0.05$} & $0.60 \pm 0.16$ & $0.86 \pm 0.10$ & $>0.05$ \\
\hline & S & $0.50 \pm 0.19$ & & $0.89 \pm 0.06$ & & $0.50 \pm 0.19$ & $0.89 \pm 0.06$ & $<0.05$ \\
\hline \multirow{2}{*}{ Differentiated } & NS & $418.00 \pm 36.26$ & \multirow{2}{*}{$>0.05$} & $375.29 \pm 33.70$ & \multirow{2}{*}{$>0.05$} & $418.00 \pm 36.26$ & $375.29 \pm 33.70$ & $>0.05$ \\
\hline & S & $439.38 \pm 26.20$ & & $310.89 \pm 19.89$ & & $439.38 \pm 26.20$ & $310.89 \pm 19.89$ & $<0.05$ \\
\hline \multirow{2}{*}{ Binucleated } & NS & $2.40 \pm 0.34$ & \multirow{2}{*}{$>0.05$} & $2.57 \pm 0.31$ & \multirow{2}{*}{$>0.05$} & $2.40 \pm 0.34$ & $2.57 \pm 0.31$ & $>0.05$ \\
\hline & S & $3.24 \pm 0.49$ & & $2.96 \pm 0.22$ & & $3.24 \pm 0.49$ & $2.96 \pm 0.22$ & $>0.05$ \\
\hline \multirow{2}{*}{ Micronucleated } & NS & $4.30 \pm 0.30$ & \multirow{2}{*}{$<0.05$} & $6.21 \pm 0.33$ & \multirow{2}{*}{$<0.05$} & $4.30 \pm 0.30$ & $6.21 \pm 0.33$ & $<0.05$ \\
\hline & S & $6.50 \pm 0.46$ & & $8.63 \pm 0.49$ & & $6.50 \pm 0.46$ & $8.63 \pm 0.49$ & $<0.05$ \\
\hline \multirow{2}{*}{ Condensed } & NS & $1.60 \pm 0.37$ & \multirow{2}{*}{$>0.05$} & $2.50 \pm 0.36$ & \multirow{2}{*}{$>0.05$} & $1.60 \pm 0.37$ & $2.50 \pm 0.36$ & $>0.05$ \\
\hline & S & $1.63 \pm 0.26$ & & $2.63 \pm 0.22$ & & $1.63 \pm 0.26$ & $2.63 \pm 0.22$ & $<0.05$ \\
\hline \multirow{2}{*}{ Karyorrhectic } & NS & $39.90 \pm 4.90$ & \multirow{2}{*}{$<0.05$} & $53.07 \pm 3.57$ & \multirow{2}{*}{$>0.05$} & $39.90 \pm 4.90$ & $53.07 \pm 3.57$ & $>0.05$ \\
\hline & S & $66.88 \pm 6.54$ & & $57.15 \pm 3.02$ & & $66.88 \pm 6.54$ & $57.15 \pm 3.02$ & $>0.05$ \\
\hline \multirow{2}{*}{ Pycnotic } & NS & $101.90 \pm 10.13$ & \multirow{2}{*}{$<0.05$} & $110.79 \pm 6.89$ & \multirow{2}{*}{$>0.05$} & $101.90 \pm 10.13$ & $110.79 \pm 6.89$ & $>0.05$ \\
\hline & S & $131.00 \pm 5.79$ & & $119.41 \pm 5.89$ & & $131.00 \pm 5.79$ & $119.41 \pm 5.89$ & $>0.05$ \\
\hline \multirow{2}{*}{ Karyolytic } & NS & $431.30 \pm 44.19$ & \multirow{2}{*}{$>0.05$} & $449.50 \pm 35.86$ & \multirow{2}{*}{$>0.05$} & $431.30 \pm 44.19$ & $449.50 \pm 35.86$ & $>0.05$ \\
\hline & $\mathrm{S}$ & $350.88 \pm 25.83$ & & $498.56 \pm 21.65$ & & $350.88 \pm 25.83$ & $498.56 \pm 21.65$ & $<0.05$ \\
\hline
\end{tabular}

a: Mean \pm standard error, ${ }^{*}$ : Two tailed Monte Carlo $\mathrm{p}$ Value, WCW: white collar workers, BCW: blue collar workers, NS: Non-smokers. S: Smokers.

smokers, statistically significant differences were measured in pycnotic cells. In the meantime between smokers in WCWs and BCWs statistically significant differences were observed in differentiated, condensed and karyolytic cells. 


\subsection{Micronuclei Measurements}

Micronuclei were evaluated in a total of 2000 cells per subject according to Thomas et al. [20]. Comparisons were made between smokers and non-smokers (Table 5). Additional non-parametric analysis among WCW and BCW in several working areas revealed statistically significant differences in the case of Steelworks and secondarily in the case of Demineralization. Comparing non-smokers, Office employees and those working in the production line, a strong correlation of micronuclei induction and $\mathrm{Ni}$ exposure is observed. The correlation is statistically more significant when in the comparison smokers are included. There is a strong correlation between smoking and increased micronuclei frequency between smokers and non-smokers in all workplaces. However, comparing total smokers per workplace not a very strong correlation is observed. In the meantime, there is a very strong correlation when comparing non-smokers.

\section{Discussion}

Humans are exposed to harmful agents either consciously or unconsciously. Conscious exposure occurs either occupationally or in lifestyle and can be controlled, while unconscious exposure is very dangerous. One of their primary targets is the oral epithelium. Alterations observed in buccal and nasal epithelium cells may provide indications of possible side effects from conscious or unconscious exposure to air or water soluble harmful agents. Oral epithelium cells, forming the first barrier to respiratory and digestive tract absorbing inhaled noxious agents, are capable of metabolizing carcinogens into active by-products [12]. To investigate the possibility of side effects from the exposure to such agents various bio-motoring assays have been developed. Among others, the BMCyt assay [13]-[26] act as internal dosimeter for the disclosure of specific genotoxic tissue damage in workers exposed to carcinogens [30] [31] [42] [43]. In addition, the BMCyt assay is a quick and minimally invasive method able to identify DNA damage as well as the regenerative capacity of oral mucosa epithelial cells in humans [34] [43].

Table 5. Non parametric analysis of measured micronuclei.

\begin{tabular}{|c|c|c|c|}
\hline Subjects & \multicolumn{2}{|c|}{ Mean \pm s.e. $^{a}$} & ${ }^{*} \mathrm{p}$ \\
\hline \multirow[b]{2}{*}{ WCWs } & Non-smokers & $8.60 \pm 0.60$ & \multirow[b]{2}{*}{$<0.05$} \\
\hline & Smokers & $13.00 \pm 0.93$ & \\
\hline BCWs & $\begin{array}{c}\text { Non-smokers } \\
\text { Smokers }\end{array}$ & $\begin{array}{l}12.64 \pm 0.64 \\
17.96 \pm 1.10\end{array}$ & $<0.05$ \\
\hline \multirow[b]{2}{*}{ WCWs / BCWs } & Non-smokers & $\begin{array}{c}8.60 \pm 0.60 \\
12.64 \pm 0.64\end{array}$ & $<0.05$ \\
\hline & Smokers & $\begin{array}{l}13.00 \pm 0.93 \\
17.96 \pm 1.10\end{array}$ & $<0.05$ \\
\hline
\end{tabular}

a: Mean \pm standard error, ${ }^{\star}$ p: Two tailed Monte Carlo p Value, WCWs: white collar workers, BCWs: blue collar workers. 
The intention in the present study was to investigate possible side effects to $\mathrm{Ni}$ exposed workers in an important Greek Ni mining, manufacturing and processing industry. Thus, the level of $\mathrm{Ni}$ in the air of the previously referred $\mathrm{Ni}$ industry was monitored in its various workplaces. Ni measurements did not reveal increased concentrations of either soluble or insoluble Ni. Soluble Ni was detected in concentrations lower than the widely acceptable $0.01 \mathrm{mg} / \mathrm{m}^{3}$ level [40] only in the Demineralization, Dome, Electric Furnaces and Steel Works work-places. Insoluble Ni was measured below the acceptable level in the Dome, Electrical Furnaces and Forge Caretaker work-places and only in the Demineralization area it was found higher than the widely acceptable $0.01 \mathrm{mg} / \mathrm{m}^{3}$ level [40]. In all other work places insoluble or soluble Ni was not detected. Thus, the reported $\mathrm{Ni}$ measurements data indicate that the above referred industry should be considered as a rather safe working place in case that personally protective outfit is applied throughout the plant.

According to published data, cigarettes and tobacco and in consequence their smoke contains Ni. Its content is estimated at $2.32-4.20 \mathrm{mg} / \mathrm{kg}$ and $2.20-4.91$ $\mathrm{mg} / \mathrm{kg}$ in smoke, while the presence of $\mathrm{Ni}$ in smokers' blood was not significantly different from non-smoker ones. On the contrary, $\mathrm{Ni}$ concentration in smokers' urine was significantly higher than in non-smokers [2].

The subjects of the present study were grouped in relation to their work-place, on the basis of Ni measurements and their smoking habit. Analyzing the collected samples a statistically significant increase of the number of micronuclei is observed in smoker office employees in relation to non-smoker ones indicating the contribution of smoking habit to DNA induced damage. This observation is compatible with previously reported data [44] [45] [46] [47]. In the meantime buccal epithelium appears to be affected by smoking. A statistically significant increase in micronucleated, karyorrhectic and pycnotic cells was observed in smoker office employees compared to non-smoker ones indicating a process to eliminate possible DNA damaged cells by inducing cell death. Naderi and Pasha [48] reported a compatible observation comparing cigarette and water-pipe smokers to no-smokers suggesting the cytotoxicity of cigarette smoking. Cigarette smoke cytotoxicity on alveolar and nasal epithelial cells was previously reported [49] [50].

Data of production line workers revealed a statistically increase in the total micronuclei number of smokers compared to non-smokers. Taking into consideration that in certain workplaces of the pyrometallurgic production line soluble and insoluble Ni concentration was detected, it is rather obvious that $\mathrm{Ni}$ induced DNA damage to buccal epithelial cells. The statistical analysis of the various buccal epithelial cells, undergoing cell death, among non-smoker and smoker BCW revealed only an increase in micronucleated cells. This observation enhances the suggestion that Ni should be responsible for DNA damage during the maturation of the basal cell layer of this epithelium.

Comparing the observed data between non-smoker office employees (WCW) and production line workers $(\mathrm{BCW})$ a statistically increase of micronucleated 
cells and total micronuclei was observed, further enhancing the suggestion that $\mathrm{Ni}$ induces DNA damage in buccal epithelial cells. In the meantime a comparison among the smoker ones, WCW compared to BCW, in addition to the significant increase in micronucleated cells and total micronuclei a significant increase in cells undergoing the cell death process is observed.

Our data support the suggestion that $\mathrm{Ni}$ is affecting the physiological process of the buccal epithelium inducing both DNA damage and karyorrhexis, pycnosis and karyolysis, an observation being compatible with the reported effect of cigarette smoke upon buccal epithelial cells [48]. Taking into consideration that cigarette smoke contains between 2.20 and $4.91 \mathrm{mg} \mathrm{Ni}$ per tobacco kilogram [2], the reported effect should be accounted, among other effectors, to the presence of Ni [14] [16] [32] [34] [35] [48] [51] [52].

Taking into consideration that: 1) micronuclei act as internal dosimeters for the disclosure of specific genotoxic tissue damage in workers exposed to carcinogens [30] [31] [53] [54], 2) IARC has classified soluble Ni in group 1 carcinogenic substances [11] and 3) exposure to soluble forms of $\mathrm{Ni}$ has been associated with higher mortality and a high risk for lung cancer [5] [6] [7] [8] [9] [10], it is rather intriguing not to consider the high risk the smoker plant workers, particularly those working to the workplaces where either insoluble or soluble $\mathrm{Ni}$ was detected, are exposed, as smoking may play an important role in causing cell damage and triggering early genotoxic events. An elongated period of electroplating was associated with increased micronuclei induction in buccal mucosa cells in non-smokers [23] [54], as well as in blood leucocytes [55] where $\mathrm{Ni}$ and $\mathrm{Cr}$ were measured in subjects' plasma and not in their workplaces. It is well documented that micronuclei are a product of the early stages of the carcinogenic process in humans [32] [51]-[59].

The analysis of our data supports the micronuclei induction due to Ni inhalation and smoking habit which they possibly work synergistically. It must be noted that significant induction of micronuclei frequencies in human peripheral blood lymphocytes has been observed in heavy smokers occupationally exposed to various noxious agents [33], indicating the relationship and the synergistic effect of smoking and noxious agents in inducing genotoxic damages.

The non-parametric analysis indicates that the soluble form of $\mathrm{Ni}$ induces cellular alterations that trigger early genotoxic effects. Smoking appears to act synergistically on the possible side effects of occupational exposure to soluble forms of $\mathrm{Ni}$, as statistically significant induction of micronuclei and/or other cellular lesions were observed in workers in the Demineralization, Electrical Furnaces and Steelworks areas of the plant where soluble forms of Ni were detected.

\section{Conclusions}

The working environment of this particular Greek nickel processing industry, with regard to nickel concentration in the breathable and inhalable fraction of 
suspended particles in the air in the various positions of its production line, appears to be adequate for those participating in its activities taking into consideration that production line workers use their personal protection outfits. Taking into consideration our findings and the potential risks to the health of workers exposed to nickel, the company's management could take the following measures: 1) Air quality measurements every six months to determine the concentration of soluble and insoluble $\mathrm{Ni}$ forms 2) To reconsider the personal protective equipment characteristics that are in use at the various sites of its production line 3) The company's occupational physician requires examining the workers of the suspicious areas, for soluble forms of $\mathrm{Ni}$, at least once every three months.

Analyzing the BMCyt data, buccal cell lesions and micronuclei frequencies were observed as a result of workers exposure to Ni. In addition, smoking habit induced the micronuclei frequency to office employees and a synergistic with nickel activity on the induction of the observed lesions is attested.

The above reported data confirm the IARC classification of soluble and metallic nickel forms with regard to their carcinogenic potential [11].

\section{Conflicts of Interest}

The authors declare no conflicts of interest regarding the publication of this paper.

\section{References}

[1] Chadwick, J.K., Wilson, H.K. and White, M.A. (1997) An Investigation of Occupational Metal Exposure in Thermal Spraying Processes. Science of the Total Environment, 199, 115-124. https://doi.org/10.1016/S0048-9697(97)05487-9

[2] Stojanović, D., Nikić, D. and Lazarević, K. (2004) The Level of Nickel in Smoker's Blood and Urine. Central European Journal of Public Health, 12, 187-189.

[3] WHO/Europe (1990) Report of the International Committee on Nickel Carcinogenesis in Man. Scandinavian Journal of Work, Environment \& Health, 16, 1-84. https://doi.org/10.5271/sjweh.1813

[4] ATSDG. Agency for Toxic Substances and Disease Registry (2005) Toxicological Profile for Nickel. https://www.atsdr.cdc.gov/toxprofiles/tp15.pdf

[5] Roberts, R.S., Julian, J.A., Muir, D.C. and Shannon, H.S. (1989) A Study of Mortality in Workers Engaged in the Mining, Smelting, and Refining of Nickel. II: Mortality from Cancer of the Respiratory Tract and Kidney. Toxicology and Industrial Health, 5, 975-993. https://doi.org/10.1177/074823378900500606

[6] Magnus, K., Andersen, A. and Høgetveit, C. (1982) Cancer of Respiratory Organs among Workers at a Nickel Refinery in Norway. International Journal of Cancer, 30, 681-685. https://doi.org/10.1002/ijc.2910300602

[7] Godbold, J.H. and Tompkins, E.A. (1979) A Long-Term Mortality Study of Workers Occupationally Exposed to Metallic Nickel at the Oak Ridge Gaseous Diffusion Plant. Journal of Occupational Medicine, 21, 799-806.

[8] Cox, J.E., Doll, R., Scott, W.A. and Smith, S. (1981) Mortality of Nickel Workers: Experience of Men Working with Metallic Nickel. British Journal of Industrial Medicine, 38, 235-239. 
[9] Grimsrud, T.K., Berge, S.R., Haldorsen, T. and Andersen, A. (2002) Exposure to Different Forms of Nickel and Risk of Lung Cancer. American Journal of Epidemiology, 156, 1123-1132. https://doi.org/10.1093/aje/kwf165

[10] Anttila, A., Pukkala, E., Aitio, A., Rantanen, T. and Karjalainen, S. (1998) Update of Cancer Incidence among Workers at a Copper/Nickel Smelter and Nickel Refinery. International Archives of Occupational and Environmental Health, 71, 245-250. https://doi.org/10.1007/s004200050276

[11] IARC. International Agency for Research on Cancer (1990) Monographs on the Evaluation of Carcinogenic Risks to Humans: Chromium, Nickel and Welding. World Heal Organ, 49, 49-445.

https://monographs.iarc.fr/iarc-monographs-on-the-evaluation-of-carcinogenic-ris ks-to-humans-72/

[12] Vondracek, M., Xi, Z., Larsson, P., Baker, V., Mace, K., Pfeifer, A., et al. (2001) Cytochrome P450 Expression and Related Metabolism in Human Buccal Mucosa. Carcinogenesis, 22, 481-488. https://doi.org/10.1093/carcin/22.3.481

[13] Karahalil, B., Karakaya, A.E. and Burgaz, S. (1999) The Micronucleus Assay in Exfoliated Buccal Cells: Application to Occupational Exposure to Polycyclic Aromatic Hydrocarbons. Mutation Research, 442, 29-35.

https://doi.org/10.1016/S1383-5718(99)00055-8

[14] Benova, D., Hadjidekova, V., Hristova, R., Nikolova, T., Boulanova, M., Georgieva, I., et al. (2002) Cytogenetic Effects of Hexavalent Chromium in Bulgarian Chromium Platters. Mutation Research, 514, 29-38. https://doi.org/10.1016/S1383-5718(01)00320-5

[15] Çelik, A., Çavaş, T. and Ergene-Gözükara, S. (2003) Cytogenetic Biomonitoring in Petrol Station Attendants: Micronucleus Test in Exfoliated Buccal Cells. Mutagenesis, 18, 417-421. https://doi.org/10.1093/mutage/geg022

[16] Pastor, S., Creus, A., Parrón, T., Cebulska-Wasilewska, A., Siffel, C., Piperakis, S., et al. (2003) Biomonitoring of Four European Populations Occupationally Exposed to Pesticides: Use of Micronuclei as Biomarkers. Mutagenesis, 18, 249-258. https://doi.org/10.1093/mutage/18.3.249

[17] Popova, L., Kishkilova, D., Hadjidekova, V.D., Hristova, R.P., Atanasova, P., Hadjidekova, V.V., et al. (2007) Micronucleus Test in Buccal Epithelium Cells from Patients Subjected to Panoramic Radiography. Dentomaxillofacial Radiology 36, 168-171. https://doi.org/10.1016/j.mrrev.2008.03.007

[18] Holland, N., Bolognesi, C., Kirsch-Volders, M., Bonassi, S., Zeiger, E., Knasmueller, S., et al. (2008) The Micronucleus Assay in Human Buccal Cells as a Tool for Biomonitoring DNA Damage: The HUMN Project Perspective on Current Status and Knowledge Gaps. Mutation Research, 659, 93-108.

https://doi.org/10.1016/j.mrrev.2008.03.007

[19] Hallare, A.V., Gervasio, M.K.R., Gervasio, P.L.G. and Acacio-Claro, P.J.B. (2009) Monitoring Genotoxicity among Gasoline Station Attendants and Traffic Enforcers in the City of Manila Using the Micronucleus Assay with Exfoliated Epithelial Cells. Environmental Monitoring and Assessment, 156, 331-341. https://doi.org/10.1007/s10661-008-0488-y

[20] Thomas, P., Holland, N., Bolognesi, C., Kirsch-Volders, M., Bonassi, S., Zeiger, E., et al. (2009) Buccal Micronucleus Cytome Assay. Nature Protocols, 4, 825-837. https://doi.org/10.1038/nprot.2009.53

[21] Celik, A., Diler, S.B. and Eke, D. (2010) Assessment of Genetic Damage in Buccal Epithelium Cells of Painters: Micronucleus, Nuclear Changes, and Repair Index. 
DNA and Cell Biology, 29, 277-284. https://doi.org/10.1089/dna.2009.0996

[22] Diler, S.B. and Ergene, S. (2010) Nuclear Anomalies in the Buccal Cells of Calcite Factory Workers. Genetics and Molecular Biology, 33, 374-378. https://doi.org/10.1590/S1415-47572010005000021

[23] Jyoti, S., Khan, S., Afzal, M. and Siddique, Y.H. (2012) Micronucleus Investigation in Human Buccal Epithelial Cells of Gutkha Users. Advanced Biomedical Research, 1, 35. https://doi.org/10.4103/2277-9175.100128

[24] Qayyum, S., Ara, A. and Usmani, J.A. (2012) Effect of Nickel and Chromium Exposure on Buccal Cells of Electroplaters. Toxicology and Industrial Health, 28, 74-82. https://doi.org/10.1177/0748233711407237

[25] Benedettia, D., Nunesa, E., Sarmentoa, M., Portoa, C., Eliete, C., dos Santosb, I., et al. (2013) Genetic Damage in Soybean Workers Exposed to Pesticides: Evaluation with the Comet and Buccal Micronucleus Cytome Assays. Mutation Research, 752, 28-33. https://doi.org/10.1016/j.mrgentox.2013.01.001

[26] Sagari, S.G., Babannavar, R., Lohra, A., Kodgi, A., Bapure, S., Rao, Y., et al. (2014) Micronuclei Frequencies and Nuclear Abnormalities in Oral Exfoliated Cells of Nuclear Power Plant Workers. Journal of Clinical and Diagnostic Research, 8, 15-17. https://doi.org/10.7860/JCDR/2014/9059.5240

[27] Kirsch-Volders, M., Vanhauwaert, A., De Boeck, M. and Decordier, I. (2002) Importance of Detecting Numerical versus Structural Chromosome Aberrations. $\mathrm{Mu}$ tation Research, 504, 137-148. https://doi.org/10.1016/S0027-5107(02)00087-8

[28] Kirsch-Volders, M., Plas, G., Elhajouji, A., Lukamowicz, M., Gonzalez, L., Loock, K.V., et al. (2011) The in Vitro MN Assay in 2011: Origin and Fate, Biological Significance, Protocols, High Throughput Methodologies and Toxicological Relevance. Archives of Toxicology, 85, 873-899. https://doi.org/10.1007/s00204-011-0691-4

[29] Duesberg, P. and Rasnick, D. (2000) Aneuploidy, the Somatic Mutation That Makes Cancer a Species of Its Own. Cell Motility and the Cytoskeleton, 47, 81-107. https://doi.org/10.1002/1097-0169(200010)47:2<81::AID-CM1>3.0.CO;2-\#

[30] Stich, H.F., Acton, A.B. and Palcic, B. (1990) Towards an Automated Micronucleus Assay as an Internal Dosimeter for Carcinogen-Exposed Human Population Groups. Recent Results in Cancer Research, 120, 94-105. https://doi.org/10.4172/2155-9929.1000236

[31] Yadav, A.S. and Jaggi, S. (2015) Buccal Micronucleus Cytome Assay. A Biomarker of Genotoxicity. Journal of Molecular Biomarkers \& Diagnosis, 6, 236-241. https://doi.org/10.4172/2155-9929.1000236

[32] Stich, H.F., Rosin, M.P., Hornby, A.P., Mathew, B., Sankaranarayanan, R. and Nair, M.K. (1998) Remission of Oral Leukoplakias and Micronuclei in Tobacco/Betel Quid Chewers Treated with Beta-Carotene and with Beta-Carotene Plus Vitamin A. International Journal of Cancer, 42, 195-199. https://doi.org/10.1002/ijc.2910420209

[33] Bonassi, S., Neri, M., Lando, C., Ceppi, M., Lin, Y.-P., Chang W.P., et al. (2003) Effect of Smoking Habit on the Frequency of Micronuclei in Human Lymphocytes: Results from the Human MicroNucleus project. Mutation Research, 543, 155-156. https://doi.org/10.1016/S1383-5742(03)00013-9

[34] Proia, N.K., Paszkiewicz, G.M., Nasca, M.A.S., Franke, G.E. and Pauly, J.L. (2006) Smoking and Smokeless Tobacco-Associated Human Buccal Cell Mutations and Their Association with Oral Cancer-A Review. Cancer Epidemiology Biomarkers \& Prevention, 15, 1061-1077. https://doi.org/10.1158/1055-9965.EPI-05-0983

[35] Naderi, N.J., Farhadi, S. and Sarshar, S. (2012) Micronucleus Assay of Buccal Mucosa Cells in Smokers with the History of Smoking Less and More than 10 Years. 
Indian Journal of Pathology and Microbiology, 55, 433-438.

https://doi.org/10.4103/0377-4929.107774

[36] HSE (Health and Safety Executive). Methods for the Determination of Hazardous Substances: MDHS 42/2 Nickel and Inorganic Compounds of Nickel in Air (Except Nickel Carbonyl) and MDHS 46/2.

http://amcaw.ifa.dguv.de/substance/sheets/076-02-S-Nickel.pdf

[37] HSE (Health and Safety Executive). Nickel and Its Inorganic Compounds: Health Hazards and Precautionary Measures. Guidance Note EH60.

https://www.hsl.gov.uk/media/1235788/eh60\%20ni\%20health\%20haz\%20\&\%20prec \%20measures\%20current\%20guidance.pdf

[38] IOM. Institute of Occupational Medicine. Guidance for collection of Inhalable and Respirable Ni Dust.

http://www.nickelconsortia.eu/assets/files/library/Guidances/IOM\%20Report\%201_ inhala-

tion\%20and\%20respirably\%20monitoring\%20guidance\%20for\%20Ni_March\%2020 12.pdf

[39] Theakston, F. (2000) Air Quality Guidelines for Europe. 2nd Edition, WHO Regional Publications, European Series, No. 91, 162-165.

http://www.euro.who.int/_data/assets/pdf_file/0005/74732/E71922.pdf

[40] ECA (European Chemicals Agency). Evaluation of Occupational Exposure Limits (OELs) for Nickel, Acrylonitrile and Benzene. RAC Opinions.

https://chemycal.com/news/bb60c4e5-70ce-4a88-9cdc-0de62c08e76b/Evaluation_of _occupational_exposure_limits_OELs_for_Nickel_Acrylonitrile_and_Benzene_RA C_Opinions

[41] Tolbert, P.E., Shy, C.M. and Allen, J.W. (1992) Micronuclei and Other Nuclear Anomalies in Buccal Smears: Methods Development. Mutation Research, 271, 69-77. https://doi.org/10.1016/0165-1161(92)90033-I

[42] Bonassi, S., Coskun, E., Ceppi, M., Lando, C., Bolognesi, C., Burgaz, S., et al. (2011) The Human MicroNucleus Project on Exfoliated Buccal Cells (HUMN(XL)): The Role of Life-Style, Host Factors, Occupational Exposures, Health Status, and Assay Protocol. Mutation Research, 728, 88-97.

https://doi.org/10.1016/j.mrrev.2011.06.005

[43] Kashyap, B. and Reddy, P. (2012) Micronuclei Assay of Exfoliated Oral Buccal Cells: Means to Assess the Nuclear Abnormalities in Different Diseases. Journal of Cancer Research and Therapeutics, 8, 184-191. https://doi.org/10.4103/0976-237X.96825

[44] Bansal, H., Sandhu, V.S., Bhandari, R. and Sharma, D. (2012) Evaluation of Micronuclei in Tobacco Users: A Study in Punjabi Population. Contemporary Clinical Dentistry, 3, 184-187. https://doi.org/10.4103/0976-237X.96825

[45] Pradeep, M.R., Guruprasad, Y., Jose, M., Saxena, K., Deepa, K. and Prabhu, V. (2014) Comparative Study of Genotoxicity in Different Tobacco Related Habits Using Micronucleus Assay in Exfoliated Buccal Epithelial Cells. Journal of Clinical and Diagnostic Research, 8, ZC21-ZC24.

[46] De Geus, J.L., Wambier, L.M., Bortoluzzi, M.C., Loguercio, A.D., Kossatz, S. and Reis, A. (2018) Does Smoking Habit Increase the Micronuclei Frequency in the Oral Mucosa of Adults Compared to Non-Smokers? A Systematic Review and Meta-Analysis. Clinical Oral Investigations, 22, 81-89. https://doi.org/10.1007/s00784-017-2246-4

[47] Tomiazzi, J.S., Judai, M.A., Nai, G.A., Pereira, D.R., Antunes, P.A. and Favareto, A.P.A. (2018) Evaluation of Genotoxic Effects in Brazilian Agricultural Workers 
Exposed to Pesticides and Cigarette Smoke Using Machine-Learning Algorithms. Environmental Science and Pollution Research, 25, 1259-1269. https://doi.org/10.1007/s11356-017-0496-y

[48] Naderi, N.J. and Pasha, M.P. (2017) Comparison of Cytotoxic Effect of Cigarette and Waterpipe Smoking on Human Buccal Mucosa. International Journal of Preventive Medicine, 8, 98.

[49] Hoshino, Y., Moi, T., Nagai, S., Miki, H., Ito, I., Izumi, T., et al. (2001) Cytotoxic Effects of Cigarette Smoke Extract on an Alveolar Type II Cell-Derived Cell Line. American Journal of Physiology-Lung Cellular and Molecular Physiology, 281, L509-L516. https://doi.org/10.1152/ajplung.2001.281.2.L509

[50] Comer, D.M., Elborn, J.S. and Ennis, M. (2014) Inflammatory and Cytotoxic Effects of Acrolein, Nicotine, Acetylaldehyde and Cigarette Smoke Extract on Human Nasal Epithelial Cells. BMC Pulmonary Medicine, 14, 32-42. https://doi.org/10.1186/1471-2466-14-32

[51] Stich, H.F. and Rosin, M.P. (1984) Micronuclei in Exfoliated Human Cells as a Tool for Studies in Cancer Risk and Cancer Intervention. Cancer Letters, 22, 241-253. https://doi.org/10.1016/0304-3835(84)90159-9

[52] Ghosh, U.R. and Parida, B.B. (1995) Cytological Study of Exfoliated Buccal Mucosa Cells of Tribes in Orissa State (India) with High Risk for Oral Cancer. Indian Journal of Cancer, 32, 95-99.

[53] Danadevi, K., Rozati, R., Banu, B.S. and Grover, P. (2004) Genotoxic Evaluation of Welders Occupationally Exposed to Chromium and Nickel Using the Comet and Micronucleus Assays. Mutagenesis, 19, 35-41.

https://doi.org/10.1093/mutage/geh001

[54] Wultsch, G., Nersesyan, A., Kundi, M., Jakse, R., Beham, A., Wagner, K.-H., et al. (2014) The Sensitivity of Biomarkers for Genotoxicity and Acute Cytotoxicity in Nasal and Buccal Cells of Welders. International Journal of Hygiene and Environmental Health, 217, 492-498. https://doi.org/10.1016/j.ijheh.2013.09.005

[55] Desai, S.S., Ghaisas, S.D., Jakhi, S.D. and Bhide, S.V. (1996) Cytogenetic Damage in Exfoliated Oral Mucosal Cells and Circulating Lymphocytes of Patients Suffering from Precancerous Oral Lesions. Cancer Letters, 109, 9-14. https://doi.org/10.1016/S0304-3835(96)04390-X

[56] Stich, H.F., Stich, W. and Parida, B.B. (1982) Elevated Frequency of Micronucleated Cells in the Buccal Mucosa of Individuals at High Risk for Oral Cancer: Betel Quid Chewers. Cancer Letters, 17, 125-134. https://doi.org/10.1016/0304-3835(82)90024-6

[57] Dave, B.J., Trivedi, A.H. and Adhvaryu, S.G. (1992) Role of Areca Nut Consumption in the Cause of Oral Cancers. A Cytogenetic Assessment. Cancer, 70, 1017-1023. https://doi.org/10.1002/1097-0142(19920901)70:5<1017::AID-CNCR2820700502>3. 0.CO;2-\#

[58] Benner, S.E., Lippman, S.M., Wargovich, M.J., Lee, J.J., Velasco, M., Martin, J.W., et al. (1994) Micronuclei, a Biomarker for Chemoprevention Trials: Results of a Randomized Study in Oral Pre-Malignancy. International Journal of Cancer, 59, 457-459. https://doi.org/10.1002/ijc.2910590403

[59] Roberts, D.M. (1997) Comparative Cytology of the Oral Cavities of Snuff Users. Acta Cytologica, 41, 1008-1014. https://doi.org/10.1159/000332781 